\title{
Pengaruh Net Profit Margin, Return On Asset, Return On Equity, dan Earning Per Share Terhadap Harga Saham Di Masa Pandemi Covid-19 (Studi Empiris Pada Perusahaan Publik Sektor Pertambangan Di Bursa Efek Indonesia)
}

\author{
Received: \\ 9 Juli 2021 \\ Nafis Dwi Kartiko* dan Ismi Fathia Rachmi \\ Revision \\ Program Studi Akuntansi, Universitas Bina Nusantara, Indonesia
}

received:

14 Juli 2021

Accepted:

4 Agustus 2021

\begin{abstract}
:
The COVID-19 pandemic has caused disruptions in demand and sales of mining materials. The aftermath of the event affected world mining production. This will certainly affect the Share Price of mining sector companies on the Indonesia Stock Exchange (IDX). This study aims to determine the influence of Net Profit Margin (NPM), Return On Asset (ROA), Return On Equity (ROE), and Earning Per Share (EPS) on Share Prices. The population in this study is mining sector companies registered in IDX period 2020 as many as 49 companies. The data collected comes from the interim financial report data published by IDX every month from March 2020 to December 2020. The analysis method used is multiple linear regression analysis with the help of SPSS 23 software. The results showed that NPM, ROA, ROE, and EPS had a significant impact on the share price.
\end{abstract}

Keywords: EPS, share price, NPM, ROA, ROE

\begin{abstract}
Abstrak:
Pandemi COVID-19 setidaknya memiliki dampak dalam jangka pendek, menengah, dan panjang bagi industri sektor pertambangan. Tekanan pada industri pertambangan disebabkan oleh kegiatan tambang dunia yang mengalami gangguan permintaan dan penjualan bahan tambang selama pandemi COVID-19. Akibat peristiwa tersebut mempengaruhi produksi pertambangan dunia. Hal tersebut tentu akan memengaruhi harga saham perusahaan sektor pertambangan di Bursa Efek Indonesia (BEI). Penelitian ini bertujuan untuk mengetahui pengaruh Net Profit Margin (NPM), Return On Asset (ROA), Return On Equity (ROE), dan Earning Per Share (EPS) terhadap harga saham. Populasi dalam penelitian ini adalah perusahaan sektor pertambangan yang terdaftar di BEI periode 2020 sebanyak 49 perusahaan. Data yang dihimpun berasal dari data laporan keuangan interim yang dipublikasi BEI setiap bulannya dengan rentang Maret 2020 sampai dengan Desember 2020. Metode analisis yang digunakan adalah analisis regresi linear berganda dengan bantuan software SPSS 23. Hasil penelitian menunjukkan bahwa NPM, ROA, ROE, dan EPS berpengaruh signifikan terhadap harga saham.
\end{abstract}

Kata kunci: EPS, harga saham, NPM, ROA, ROE

Pendahuluan

World Health Organization (WHO) telah menyatakan coronavirus disease (COVID-19) sebagai pandemi pada bulan Maret 2020. Indonesia sendiri pertama kali mengonfirmasi kasus COVID-19 pada tanggal 2 Maret 2020. Masifnya penyebaran COVID-19 membuat peningkatan kasus positif virus ini begitu cepat. Terdata sampai dengan 10 April 2021 di Indonesia sudah terdapat 1.562.868 kasus positif dengan kasus 42.443 orang meninggal dan 1.409.288 dinyatakan sembuh. 
Berbagai upaya dilakukan oleh pemerintah untuk mengurangi penyebaran COVID-19 yang lebih luas. Upaya tersebut diantaranya dituangkan dalam kebijakan social distancing yang telah dilakukan sejak awal Maret 2020. Kebijakan social distancing merupakan salah satu kebijakan yang direkomendasikan oleh WHO untuk menghentikan penularan virus ini, dan telah diterapkan di beberapa negara. Kebijakan social distancing mengharuskan masyarakat menjaga jarak dan mengurangi aktivitas di tempat umum untuk menghentikan penyebaran virus. Kebijakan ini telah menimbulkan gangguan pada rantai nilai dunia usaha, sehingga banyak usaha di berbagai sektor berhenti operasi baik sementara maupun permanen. Gangguan ini diperkirakan mengakibatkan pertumbuhan ekonomi global menurun 4,5\% sampai dengan 6\%. Di Indonesia sendiri, berdasarkan hasil rilis dari Badan Pusat Statistik (BPS) untuk tahun 2020, pertumbuhan ekonomi mengalami kontraksi sebesar 2,07 persen dibandingkan tahun 2019.

Kebijakan dan tekanan selama pandemi COVID-19 telah menyebabkan malapetaka pada ekonomi global. Salah satu sektor dalam perekonomian yang mengalami tekanan ekonomi akibat pandemi COVID-19 adalah sektor pertambangan. Padahal industri pertambangan merupakan industri yang merupakan salah satu produsen dan eksportir terbesar di dunia. Dalam studi yang dilakukan Timothy Laing dalam "The economic impact of the Coronavirus 2019 (Covid-2019): Implications for the mining industry" menyebutkan bahwa pandemi COVID-19 memiliki dampak dalam jangka pendek, menengah, dan panjang bagi industri sektor pertambangan.

Tekanan pada industri pertambangan disebabkan oleh kegiatan tambang dunia yang mengalami gangguan permintaan dan penjualan bahan tambang selama pandemi COVOD-19. Akibat peristiwa tersebut mempengaruhi produksi pertambangan dunia. Di Indonesia sendiri hal ini berimplikasi pada keputusan perusahaan untuk merumahkan karyawan dan menghentikan kegiatan pertambangan. Dengan menurunnya produksi pertambangan, tentu hal ini akan mempengaruhi kinerja keuangan perusahaan. Kinerja keuangan yang melemah akan mempengaruhi laba perusahaan. Semakin baik kinerja keuangan maka akan semakin baik pula laba yang dihasilkan, hal ini akan berpengaruh terhadap naiknya harga saham perusahaan karena banyaknya permintaan akan saham tersebut. Mengingat dampak secara ekonomi pandemi COVID-19 terhadap sektor pertambangan sedemikian penting, dalam penelitian ini peneliti bermaksud untuk menguji pengaruh kinerja keuangan melalui rasio keuangan antara lain Net Profit Margin (NPM), Return on Asset (ROA), Return on Equity (ROE), dan Earning Per Share Ratio (EPS) terhadap harga saham untuk perusahaan publik pada sektor pertambangan melalui studi empiris di Bursa Efek Indonesia.

\section{Kajian Literatur}

Kinerja Keuangan

Kinerja keuangan perusahaan dapat diukur dengan berbagai macam rasio keuangan. Beberapa contoh pengukuran financial performances dalam penelitian dapat dilihat pada tabel berikut.

Tabel 1. Pengukuran Kinerja Keuangan dalam Berbagai Penelitian

\begin{tabular}{|l|l|}
\hline Penelitian & Metode Pengukuran Kinerja Keuangan \\
\hline Bacidore et al., (1997) & (1) Refined economic value added (REVA) \\
& (2) Economic value added (EVA) \\
\hline Cochran \& Wood (1984) & (1) The ratio of operating earnings to assets \\
& (2) The ratio of operating earnings to sales \\
& (3) Excess market valuation \\
\hline Ramzan et al., (2021) & (1) Return on Assets (ROA) \\
& (2) Return on Equity (ROE) \\
& (3) Earnings per Share (EPS) \\
(4) Net Profit Margin (NPM) \\
\hline Barauskaite \& Streimikiene (2021) & (1) Return on Assets (ROA) \\
& (2) Return on Equity (ROE) \\
& (3) Return on share \\
& (4) Company marketvalue \\
& (5) Change in return on shares \\
& (6) Change in return on shares \\
\hline
\end{tabular}


(7) Return on sales (ROS)

(8) Return on capital employed (ROCE)

\section{Net Profit Margin (NPM)}

Net profit margin (NPM) merupakan salah satu rasio profitabilitas yang mengukur persentase setiap penjualan yang tersisa setelah dikurangi dengan semua biaya dan pengeluaran, termasuk bunga, pajak, dan dividen saham preferen (Zutter \& Gitman, 2015). Semakin tinggi net profit margin sebuah perusahaan, maka akan dianggap semakin baik. Margin laba bersih dihitung dengan cara membandingkan antara laba setelah pajak dengan penjualan netto.

\section{Return on Asset (ROA)}

Return on Assets (ROA) adalah perbandingan antara keuntungan sebelum biaya bunga dan pajak dengan seluruh aktiva atau kekayaan perusahaan. Rasio ini menunjukan kemampuan perusahaan dengan seluruh modal yang ada didalamnya untuk menghasilkan keuntungan, dengan menggunakan data yang ada pada neraca dan perhitungan laba rugi perusahaan tersebut. Rasio ini mengukur tingkat pengembalian investasi perusahaan kepada investor dengan menggunakan asset yang dimiliki perusahaan. Perusahaan yang memiliki ROA yang tinggi dapat menjadikan daya tarik bagi investor. Sebaliknya jika perusahaan memiliki ROA yang rendah dapat mengurangi minat investor terhadap perusahaan tersebut.

\section{Return on Equity (ROE)}

Return on Equity merupakan rasio profitabilitas yang menggambarkan kemampuan perusahaan dalam memberi keuntungan bagi pemegang saham biasa (pemilik modal) dengan menunjukkan laba bersih yang tersedia untuk modal pemegang saham yang telah digunakan perusahaan (Almira \& Wiagustini, 2020). ROE yang semakin tinggi akan mencerminkan perusahaan yang berhasil menghasilkan keuntungan dari modal sendiri. Peningkatan ROE akan ikut mendongkrang nilai jual perusahaan yang berimbas pada harga saham.

\section{Earning Per Share Ratio (EPS)}

Earning Per Share (EPS) dapat didefinisikan laba yang menjadi hak untuk setiap pemegang satu lembar saham biasa (Susilawati, 2014). Menurut Safitri (2013), EPS menunjukkan rasio besarnya laba bersih perusahaan yang siap dibagikan bagi semua pemegang saham perusahaan. Investor yang membeli saham dapat diartikan sebagai investor yang akan membeli prospek perusahaan (Samsul, 2006). Prospek perusahaan tersebut dapat tercermin pada laba per saham, jika laba per saham lebih tinggi, maka prospek perusahaan lebih baik, sementara jika laba per saham lebih rendah berarti kurang baik. Hadianto (2008) lebih lanjut menjelaskan bahwa EPS yang lebih besar menandakan kemampuan perusahaan yang lebih besar dalam menghasilkan keuntungan bersih bagi pemegang saham, keadaan ini akan mendorong harga saham mengalami kenaikan.

\section{Penelitian Terdahulu}

Penelitian terkait pengaruh kinerja keuangan perusahaan terhadap harga saham merupakan penelitian yang penting bagi berbagai pihak. Rekomendasi dari peneliti biasanya dapat ditujukan kepada pemerintah, perusahaan, dan yang tidak kalah penting adalah para investor. Berikut adalah contoh penelitian pengaruh pengukuran kinerja keuangan perusahan terhadap harga saham.

Tabel 2. Penelitian Terdahulu

\begin{tabular}{|l|l|}
\hline Penelitian & Hasil Penelitian \\
\hline $\begin{array}{l}\text { (Watung \& Ilat, 2016); (Egam et al., 2017); } \\
\text { (Hutami, 2012); (Amalya, 2018); (Dewi \& } \\
\text { Hidayat, 2019). }\end{array}$ & $\begin{array}{l}\text { Net profit margin berpengaruh terhadap harga } \\
\text { saham }\end{array}$ \\
\hline (Husaini, 2012); (Dini \& Indarti, 2012). & $\begin{array}{l}\text { Net profit margin tidak berpengaruh terhadap } \\
\text { harga saham }\end{array}$ \\
\hline $\begin{array}{l}\text { (Watung \& Ilat, 2016); (Rinati, 2012); (Santy \& } \\
\text { Triyonowati, 2017); (Santy \& Triyonowati, }\end{array}$ & $\begin{array}{l}\text { Return on Assets berpengaruh terhadap harga } \\
\text { saham }\end{array}$ \\
\hline
\end{tabular}


2017); (Husaini, 2012); (Dewi \& Hidayat, 2019).

(Egam et al., 2017); (Valintino \& Sularto, 2013); (Amalya, 2018); (Husaini, 2012); (Dini

\& Indarti, 2012).

(Sakai \& Dillak, 2021); (Hutami, 2012); (Azhari et al., 2016); (Pratama et al., 2019);

(Valintino \& Sularto, 2013); (Santy \& Triyonowati, 2017); (Amalya, 2018)

(Alfiah \& Diyani, 2017); (Egam et al., 2017); (Dini \& Indarti, 2012).

(Sakai \& Dillak, 2021); (Firdaus \& Kasmir, 2021); (Badruzaman, 2017); (Watung \& Ilat, 2016); (Yuliani \& Supriadi, 2014); (Pratama et al., 2019); (Egam et al., 2017); (Valintino \& Sularto, 2013); (Santy \& Triyonowati, 2017); (Husaini, 2012).

(Munira et al., 2018)

Return on Assets tidak berpengaruh terhadap

harga saham

Return on Equity berpengaruh terhadap harga saham

Return on Equity tidak berpengaruh terhadap harga saham

Earning Per Share berpengaruh terhadap harga saham

Earning Per Share tidak berpengaruh terhadap harga saham

\section{Kerangka Penelitian}

Berdasarkan Gambar 1. Kerangka konseptual sebelumnya, maka hipotesis yang diajukan dalam penelitian ini adalah sebagai berikut:

1. $\mathrm{H}_{1}$ : Rasio Net Profit Margin (NPM) berpengaruh secara signifikan terhadap harga saham perusahaan publik sektor pertambangan di masa pandemi COVID-19.

2. $\mathrm{H}_{2}$ : Rasio Return on Asset (ROA) berpengaruh secara signifikan terhadap harga saham perusahaan publik sektor pertambangan di masa pandemi COVID-19

3. $\mathrm{H}_{3}$ : Rasio Return on Equity (ROE) berpengaruh secara signifikan terhadap harga saham perusahaan publik sektor pertambangan di masa pandemi COVID-19 secara parsial

4. $\mathrm{H}_{4}$ : Rasio Earning Per Share (EPS) berpengaruh secara signifikan terhadap harga saham perusahaan publik sektor pertambangan di masa pandemi COVID-19 secara parsial

5. $\mathrm{H}_{5}$ : Rasio Net Profit Margin (NPM), Return on Asset (ROA), Return on Equity (ROE), dan Earning Per Share (EPS) secara bersama-sama berpengaruh terhadap harga saham perusahaan publik sektor pertambangan di masa pandemi COVID-19.

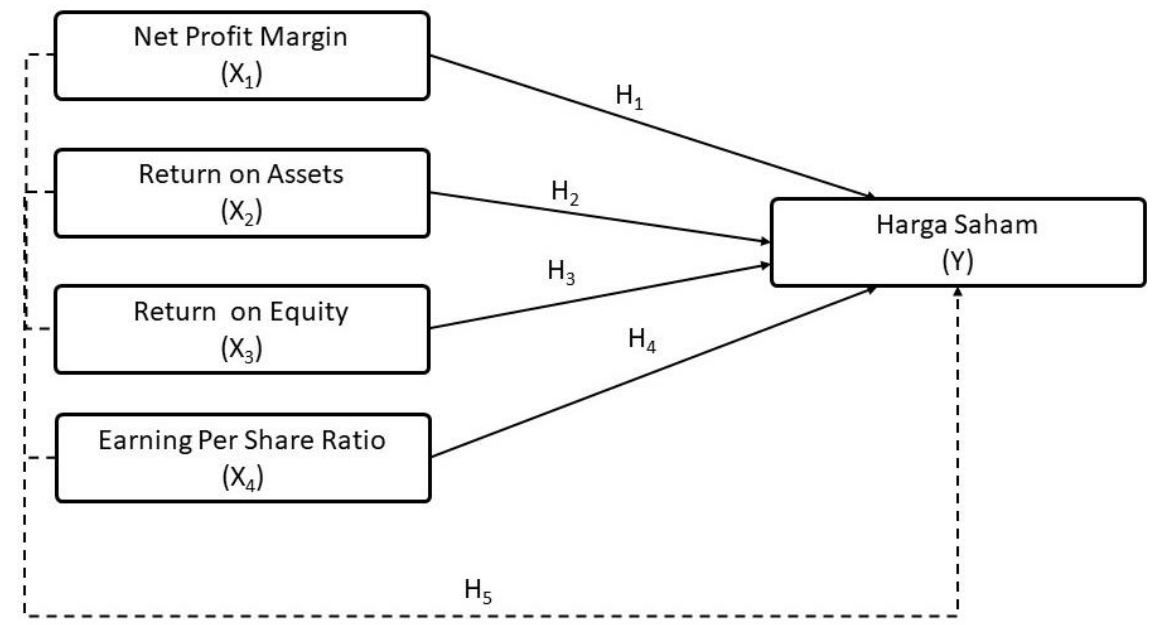

Gambar 1. Kerangka Konseptual

\section{Metode Penelitian}

Jenis, Lokasi dan Waktu Penelitian 
Jenis penelitian yang digunakan dalam penelitian ini termasuk pada penelitian kuantitatif. Penelitian kuantitatif menurut Sugiyono (2013) merupakan metode penelitian yang berlandaskan pada filsafat positivisme, digunakan untuk meneliti pada populasi atau sampel tertentu, teknik pengambilan sampel pada umumnya dilakukan secara random, pengumpulan data menggunakan instrumen penelitian, analisis data bersifat kuantitatif atau statistik dengan tujuan untuk menguji hipotesis yang telah ditetapkan. Lokasi penelitian dilakukan pada perusahaan di sektor pertambangan melalui website Bursa Efek Indonesia (www.idx.co.id). Waktu yang digunakan dalam penelitian ini dilakukan mulai bulan Maret 2020 - Desember 2020.

\section{Populasi dan Sample}

Menurut Sugiyono (2013) populasi merupakan sebagai wilayah generalisasi yang terdiri atas objek atau subjek yang mempunyai kualitas dan karakteristik tertentu yang ditetapkan oleh peneliti untuk dipelajari dan kemudian ditarik kesimpulannya. Sedangkan sampel merupakan sebagian dari populasi itu. Populasi dari penelitian ini adalah perusahaan di sektor pertambangan yang terdaftar di Bursa Efek Indonesia periode sesudah dinyatakan ada pandemi COVID-19. Adapun metode pengambilan sampel dalam penelitian ini adalah purposive sampling. Menurut Sugiyono (2016) purposive sampling merupakan teknik pengambilan sampel sumber data dengan pertimbangan tertentu. Dalam kriteria penentuan sampel adalah sebagai berikut: perusahaan di sektor pertambangan yang terdaftar di Bursa Efek Indonesia, perusahaan tersebut membuat laporan keuangan sesudah pengumuman pandemi Covid-19 dan sudah dipublikasikan melalui situs resmi www.idx.com.id, serta perusahaan mempunyai data yang dibutuhkan terkait pengukuran variabel yang akan digunakan untuk meneliti.

\section{Deskripsi Subjek Penelitian}

Penelitian ini menggunakan purposive sampling dalam pemilihan sampel yang bertujuan untuk memperoleh sampel sesuai dengan kriteria yang telah ditentukan, dimana yang menjadi subjek di penelitian ini adalah perusahaan di sektor pertambangan yang terdaftar di Bursa Efek Indonesia periode 2020. Data yang digunakan adalah laporan keuangan interim perusahaan di sektor pertambangan yang tercantum di Bursa Efek Indonesia sejak bulan Maret 2020 (sebagai bulan pertama pandemi COVID masuk ke Indonesia) sampai dengan Desember 2020.

\section{Metode Analisis Data}

Metode analisis data yang digunakan dalam penelitian ini adalah uji statistik, dikarenakan data yang digunakan adalah data kuantitatif. Penelitian ini menggunakan model regresi data panel dan uji hipotesis dalam mengambil kesimpulan. Regresi data panel dilakukan untuk menguji dan mengukur hubungan variabel dependen dengan variabel penguji dan variabel pengendali lainnya pada data gabungan cross-section dan time-series. Untuk memastikan bahwa model yang digunakan valid, maka perlu dilakukan uji normalitas dan uji asumsi klasik yang terdiri dari uji multikolinearitas, uji heteroskedastisitas, dan uji autokorelasi. Kemudian dilakukan juga uji hipotesis yang meliputi uji t, uji F, dan uji koefisien determinasi. Analisis data akan dilakukan dengan bantuan program aplikasi SPSS 23.

\section{Hasil dan Pembahasan \\ Hasil Statistik Deskriptif}

Berdasarkan tabel 1 menunjukkan bahwa jumlah data yang digunakan dalam penelitian ini 301 sampel data yang diambil di Bursa Efek Indonesia (diakses melalui situs www.idx.co.id) berikut adalah analisa deskriptif yang diperoleh dari tabel 3:

1. ROA memiliki nilai minimum sebesar 0,030; nilai maksimum sebesar 37,400; nilai rata-rata (mean) sebesar 6,44292; nilai standar deviasi sebesar 6,335256; dan nilai varian sebesar 40,135.

2. ROE memiliki nilai minimum sebesar 0,090; nilai maksimum sebesar 1.007,300; nilai rata-rata (mean) sebesar 17,43123; nilai standar deviasi sebesar 59,211337; dan nilai varian sebesar 3.505,982.

3. EPS memiliki nilai minimum sebesar 0,130; nilai maksimum sebesar 238,500; nilai rata-rata (mean) sebesar 22,24757; nilai standar deviasi sebesar 25,410031; dan nilai varian sebesar 645,670. 
4. NPM memiliki nilai minimum sebesar 0,150 ; nilai maksimum sebesar 1.597,300; nilai rata-rata (mean) sebesar 177,51276; nilai standar deviasi sebesar 268,968062; dan nilai varian sebesar $72.343,818$.

Tabel 3. Hasil Statistik Deskriptif

\begin{tabular}{|c|c|c|c|c|c|c|c|}
\hline & $\mathrm{N}$ & Range & Minimum & Maximum & Mean & Std. Deviation & Variance \\
\hline ROA & 301 & 37,370 &, 030 & 37,400 & 6,44292 & 6,335256 & 40,135 \\
ROE & 301 & 1007,210 &, 090 & 1007,300 & 17,43123 & 59,211337 & 3505,982 \\
EPS & 301 & 238,370 &, 130 & 238,500 & 22,24757 & 25,410031 & 645,670 \\
NPM & 301 & 1597,150 &, 150 & 1597,300 & 177,51276 & 268,968062 & 72343,818 \\
Valid N & 301 & & & & & & \\
(listwise) & 301 & & & & & & \\
\hline
\end{tabular}

\section{Hasil Uji Normalitas}

Kurva nilai residual terstandarisasi dianggap normal jika menggunakan nilai probability Sig (2 Tailed) lebih dari $\alpha(0,05)$. Berdasarkan hasil pengujian One Sample Kolmogorov-Smirnov Test dengan menggunakan SPSS 23 diperoleh hasil seperti yang tersaji pada Tabel 4 berikut:

Tabel 4. Hasil Uji Normalitas

\begin{tabular}{|ll|c|}
\hline & & $\begin{array}{c}\text { Unstandardized } \\
\text { Residual }\end{array}$ \\
\hline $\mathrm{N}$ & & 301 \\
Normal Parameters ${ }^{\mathrm{a}}$ & Mean & .0000000 \\
& Std. Deviation & 1.20822609 \\
Most Extreme Differences & Absolute & .062 \\
& Positive & .050 \\
& Negative & -.062 \\
Kolmogorov-Smirnov Z & & 1.073 \\
Asymp. Sig. (2-tailed) & & .200 \\
\hline
\end{tabular}

Berdasarkan hasil SPSS yang terdapat pada tabel 2 menunjukkan bahwa Asymp. Sig > 0,05 atau $0,200>0,05$ yang terdapat dalam one sample kolmogorov-smirnov test. Hasil tersebut mengartikan bahwa model regresi yang digunakan dalam penelitian berdistribusi normal sehingga model ini layak untuk dijadikan penelitian.

\section{Uji Asumsi Klasik}

\section{Uji Multikolinearitas}

Multikolinearitas merupakan suatu gejala yang menunjukkan adanya hubungan linear yang sempurna atau hampir sempurna antara dua variabel atau lebih pada model regresi. Model regresi yang baik tidak terdapat gejala multikolinearitas, cara untuk mendeteksi multikolinieritas adalah dengan menggunakan VIF (Variance Inflation Factor) dan nilai Tolerance, yaitu : apabila nilai Tolerance > 0,1 dan VIF < 10, maka tidak terjadi multikolinearitas dan apabila nilai Tolerance $<0,1$ dan VIF $>10$ maka terjadi multikolinearitas.

Berdasarkan tabel 5 dapat disimpulkan bahwa nilai Tolerance ROA sebesar 0,841; ROE sebesar 0,987; EPS sebesar 0,938; dan NPM sebesar 0,895. Nilai tolerance keseluruh variabel independen tersebut di atas 0,1. Sedangkan nilai VIF ROA sebesar 1,188; ROE sebesar 1,013; EPS sebesar 1,066; dan NPM sebesar 1,117. Nilai VIF keseluruh variabel independen tersebut kurang dari 10. Hal ini sesuai dengan syarat multikolinearitas, maka disimpulkan tidak terjadi multikolinearitas dan dapat dilakukan untuk uji selanjutnya. 
Tabel 5. Hasil Uji Multikolinearitas

\begin{tabular}{|c|c|c|c|c|c|c|c|}
\hline & \multicolumn{2}{|c|}{$\begin{array}{c}\text { Unstandardized } \\
\text { Coefficients }\end{array}$} & $\begin{array}{c}\text { Standardized } \\
\text { Coefficients }\end{array}$ & \multirow{2}{*}{} & \multicolumn{2}{|c|}{} \\
\cline { 2 - 3 } Model & $\mathrm{B}$ & Std. Error & Beta & $\mathrm{t}$ & Sig. & Tolerance & VIF \\
\hline 1 (Constant) & 5,450 &, 112 & & 48,702 &, 000 & & \\
ROA &, 062 &, 012 &, 217 & 5,264 &, 000 &, 841 & 1,188 \\
ROE &,- 003 &, 001 &,- 088 & $-2,314$ &, 021 &, 987 & 1,013 \\
EPS &,- 012 &, 003 &,- 172 & $-4,415$ &, 000 &, 938 & 1,066 \\
NPM &, 004 &, 000 &, 648 & 16,249 &, 000 &, 895 & 1,117 \\
\hline
\end{tabular}

\section{Uji Heteroskedastisitas}

Heteroskedastisitas merupakan keadaan ada atau tidak persamaan variabel dari residual pada model regresi. Model regresi yang baik harus tidak terjadi heteroskedastisitas (Glejser, 1969). Apabila nilai Sig. variabel $\mathrm{X}$ lebih dari 0,05 maka dapat dikatakan data terbebas dari gejala heteroskedastisitas, sebaliknya apabila nilai Sig < 0,05 terjadi masalah heteroskedastisitas (Bera \& Higgins, 1992).

Tabel 6. Hasil Uji Heteroskedastisitas

\begin{tabular}{|c|c|c|c|c|c|c|}
\hline & \multirow[b]{2}{*}{ Model } & \multicolumn{2}{|c|}{ Unstandardized Coefficients } & \multirow{2}{*}{$\begin{array}{c}\text { Standardized } \\
\text { Coefficients } \\
\text { Beta }\end{array}$} & \multirow[b]{2}{*}{$\mathrm{t}$} & \multirow[b]{2}{*}{ Sig. } \\
\hline & & B & Std. Error & & & \\
\hline \multirow[t]{5}{*}{1} & (Constant) & 1,554 &, 637 & & 2,438 & ,016 \\
\hline & ROA & ,013 & 060 & 020 & ,224 & ,823 \\
\hline & ROE &,- 001 & ,004 &,- 025 &,- 302 & ,763 \\
\hline & EPS &,- 010 &, 014 &,- 068 &,- 768 & ,444 \\
\hline & NPM &,- 001 & 001 &,- 056 &,- 661 &, 510 \\
\hline
\end{tabular}

Berdasarkan tabel 6 nilai signifikan masing-masing variabel yaitu ROA 0,823 >0,05; ROE 0,763 $>0,05$; EPS 0,444 >0,05; dan NPM 0,510>0,05. Sehingga dapat disimpulkan tidak terdapat masalah heteroskedastisitas dan uji selanjutnya dapat dilakukan.

\section{Uji Autokorelasi}

Autokorelasi merupakan terjadinya korelasi dari residual suatu pengamatan dengan yang lainnya yang disusun menurut runtutan waktu. Model regresi yang baik mensyaratkan tidak terjadinya autokorelasi dan metode yang digunakan yaitu dengan Uji Durbin-Watson.

Tabel 7. Hasil Uji Autokorelasi

\begin{tabular}{|c|c|c|}
\hline Model & $\begin{array}{c}\text { Std. Error of the } \\
\text { Estimate }\end{array}$ & Durbin-Watson \\
\hline 1 & 1,02076016 & 1,916 \\
\hline
\end{tabular}

Dari pengujian autokorelasi pada tabel 7 di atas didapatkan nilai Durbin-Watson hasil regresi padapenelitian ini sebesar 1,916 yang mana nilai tersebut berada diantara 1.83088 sampai dengan 2,16912 sehingga model regresi tidak terdapat autokorelasi.

\section{Hasil Regresi Linear Berganda}


Berikut adalah hasil regresi liner berganda pengaruh Net Profit Margin (NPM), Return on Asset (ROA), Return on Equity (ROE), dan Earning Per Share (EPS) terhadap harga saham:

$$
\mathrm{Y}=\alpha+\mathrm{b}_{1} \mathrm{X}_{1}+\mathrm{b}_{2} \mathrm{X}_{2}+\mathrm{b}_{3} \mathrm{X}_{3}+\mathrm{b}_{4} \mathrm{X}_{4}+\mathrm{e}
$$

Ln Harga Saham $=5,450+0,062 \mathrm{ROA}-0,003 \mathrm{ROE}-0,012 \mathrm{EPS}+0,004 \mathrm{NPM}$

Hal yang dapat diketahui dari persamaan regresi linear berganda tersebut yaitu koefisien ROA dan NPM bertanda positif yang berarti bahwa apabila koefisien ROA dan NPM tersebut mengalami peningkatan maka akan meningkatkan harga saham bidang usaha pertambangan selama pandemi COVID-19.

\section{Uji Hipotesis}

\section{Hasil Uji F}

Uji F dilakukan bertujuan untuk menguji keseluruhan variabel independen yaitu, Net Profit Margin (NPM), Return on Asset (ROA), Return on Equity (ROE), dan Earning Per Share (EPS) terhadap variabel dependen yaitu, harga saham. Secara bebas dengan signifikan sebesar 0,05, dapat disimpulkan.

a. Jika sig $\mathrm{F}<0,05$ maka $\mathrm{H} 1$ akan diterima dan $\mathrm{H0}$ akan ditolak, yang berarti semua variabel independen berpengaruh secara bersama-sama terhadap variabel dependen.

b. Jika sig F > 0,05 maka $\mathrm{H} 1$ akan ditolak dan $\mathrm{H} 0$ akan diterima, yang berarti semua variabel independen tidak berpengaruh secara bersama-sama terhadap variabel dependen.

Tabel 8. Hasil Uji F

\begin{tabular}{|ll|l|l|l|l|l|}
\hline Model & & Sum of Squares & df & Mean Square & F & Sig. \\
\hline 1 & Regression & 3735571513,964 & 4 & 933892878,491 & 175,824 &, $000^{\mathrm{b}}$ \\
& Residual & 1572211621,126 & 296 & 5311525,747 & & \\
& Total & 5307783135,090 & 300 & & & \\
\hline
\end{tabular}

a. Dependent Variable: HARGA_SAHAM

b. Predictors: (Constant), NPM, ROE, EPS, ROA

Berdasarkan tabel 8 diatas, nilai $\mathrm{F}$ sebesar 175,824 dengan signifikan F 0,000 < 0,05 maka H1 diterima dan H0 ditolak, artinya variabel Net Profit Margin (NPM), Return on Asset (ROA), Return on Equity (ROE), dan Earning Per Share (EPS) secara simultan mempengaruhi variabel harga saham.

\section{Hasil Uji Koefisien Determinasi}

Berdasarkan tabel 9 Model Summary, yaitu menunjukkan koefisien determinasi dengan nilai 0,700 atau 70\%. Artinya persentase sumbangan pengaruh variabel Net Profit Margin (NPM), Return on Assets (ROA), Return on Equity (ROE), dan Earning Per Share (EPS) terhadap harga saham sebesar 70\%, sedangkan sisanya dipengaruhi oleh variabel lain yang tidak dimasukkan dalam penelitian ini.

Tabel 9. Uji Koefisien Determinasi

\begin{tabular}{|l|l|l|l|l|}
\hline Model & $\mathrm{R}$ & R Square & $\begin{array}{l}\text { Adjusted } \\
\text { Square }\end{array}$ & $\begin{array}{l}\text { R } \\
\text { Std. Error of the } \\
\text { Estimate }\end{array}$ \\
\hline 1 &, $839^{\mathrm{a}}$ &, 704 &, 700 & 2304,674759 \\
\hline
\end{tabular}

a. Predictors: (Constant), NPM, ROE, EPS, ROA

\section{Hasil Uji t}

Uji parsial dengan menggunakan t-test dilakukan untuk menguji pengaruh semua variabel independen terhadap variabel dependen secara parsial. Apabila nilai sig t kurang dari sama dengan 0,05 maka $\mathrm{H}_{1}$ diterima yang artinya ada pengaruh secara parsial antara variabel independen dan variabel dependen.

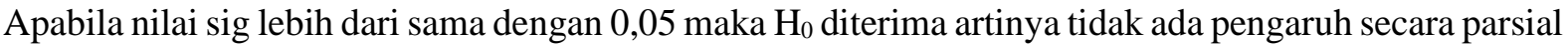
antara variabel independen terhadap variabel dependen.

Tabel 10. Hasil Uji t 


\begin{tabular}{|c|c|c|c|c|c|c|}
\hline & \multirow[b]{2}{*}{ Model } & \multicolumn{2}{|c|}{ Unstandardized Coefficients } & $\begin{array}{l}\text { Standardized } \\
\text { Coefficients }\end{array}$ & \multirow[b]{2}{*}{$\mathrm{t}$} & \multirow[b]{2}{*}{ Sig. } \\
\hline & & $\mathrm{B}$ & Std. Error & Beta & & \\
\hline 1 & (Constant) & 5,450 & ,112 & & 48,702 & ,000 \\
\hline & ROA &, 062 & ,012 & 217 & 5,264 & ,000 \\
\hline & ROE &,- 003 & 001 &,- 088 & $-2,314$ & ,021 \\
\hline & EPS &,- 012 & ,003 &,- 172 & $-4,415$ & ,000 \\
\hline & NPM & ,004 & ,000 & 648 & 16,249 & ,000 \\
\hline
\end{tabular}

Berdasarkan hasil diatas, maka hasil pembahasan pada penelitian ini adalah sebagai berikut:

1. Pengaruh Net Profit Margin (NPM) terhadap harga saham

Berdasarkan hasil diatas diperoleh uji t terhadap variabel Net Profit Margin (X1) diperoleh nilai $t$ hitung 16,249 dengan nilai signifikansi sebesar 0,000 yang berarti $0,000<0,05$ maka pengujian ini menunjukkan bahwa H1 diterima. Dengan demikian dapat disimpulkan bahwa Net Profit Margin berpengaruh positif terhadap harga saham, hipotesis ini menjelaskan bahwa Net Profit Margin berpengaruh dan berdampak terhadap harga saham.

2. Pengaruh Return on Assets (ROA) terhadap harga saham

Berdasarkan hasil diatas diperoleh uji $t$ terhadap variabel Return on Assets (X1) diperoleh nilai $t$ hitung 5,264 dengan nilai signifikansi sebesar 0,000 yang berarti $0,000<0,05$ maka pengujian ini menunjukkan bahwa H1 diterima. Dengan demikian dapat disimpulkan bahwa Return on Assets berpengaruh positif terhadap harga saham, hipotesis ini menjelaskan bahwa Return on Assets berpengaruh dan berdampak terhadap harga saham.

3. Pengaruh Return on Equity (ROE) terhadap harga saham.

Berdasarkan hasil diatas diperoleh uji t terhadap variabel Return on Equity (X1) diperoleh nilai $\mathrm{t}$ hitung -2,314 dengan nilai signifikansi sebesar 0,021 yang berarti $0,021<0,05$ maka pengujian ini menunjukkan bahwa H1 diterima. Dengan demikian dapat disimpulkan bahwa Return on Equity berpengaruh positif terhadap harga saham, hipotesis ini menjelaskan bahwa Return on Equity berpengaruh dan berdampak terhadap harga saham.

4. Pengaruh Earning Per Share (EPS) terhadap harga saham

Berdasarkan hasil diatas diperoleh uji t terhadap variabel Earning Per Share (X1) diperoleh nilai t hitung -4,415 dengan nilai signifikansi sebesar 0,000 yang berarti $0,000<0,05$ maka pengujian ini menunjukkan bahwa H1 diterima. Dengan demikian dapat disimpulkan bahwa Earning Per Share berpengaruh positif terhadap harga saham, hipotesis ini menjelaskan bahwa Earning Per Share berpengaruh dan berdampak terhadap harga saham.

\section{Kesimpulan}

Penelitian ini bertujuan untuk mengetahui pengaruh Net Profit Margin (NPM), Return on Asset (ROA), Return on Equity (ROE), dan Earning Per Share (EPS) secara bersama-sama berpengaruh terhadap harga saham perusahaan publik sektor pertambangan di masa pandemi COVID-19. Berdasarkan pada analisis regresi berganda, uji normalitas, uji asumsi klasik, dan uji hipotesis maka dapat diperoleh beberapa kesimpulan sebagai berikut: (i) variabel independen rasio Net Profit Margin (NPM) berpengaruh secara signifikan terhadap harga saham perusahaan publik sektor pertambangan di masa pandemi COVID-19 secara parsial, (ii) variabel independen rasio Return on Asset (ROA) berpengaruh secara signifikan terhadap harga saham perusahaan publik sektor pertambangan di masa pandemi COVID-19 secara parsial, (iii) variabel independen rasio Return on Equity (ROE) berpengaruh secara signifikan terhadap harga saham perusahaan publik sektor pertambangan di masa pandemi COVID-19 secara parsial, (iv) variabel independen rasio Earning Per Share (EPS) berpengaruh secara signifikan terhadap harga saham perusahaan publik sektor pertambangan di masa pandemi COVID-19 secara parsial, serta (v) rasio Net Profit Margin (NPM), Return on Asset (ROA), Return on Equity (ROE), dan Earning Per Share (EPS) secara bersama-sama berpengaruh terhadap harga saham perusahaan publik sektor pertambangan di masa pandemi COVID-19 secara simultan.

\section{Daftar Pustaka}


Alfiah, N., \& Diyani, L. A. (2017). Pengaruh ROE dan DER terhadap Harga saham Pada Sektor Perdagangan Eceran. Jurnal Bisnis Terapan, 1(02), 47-54.

Almira, N. P. A. K., \& Wiagustini, N. L. P. (2020). Return On Asset, Return On Equity, Dan Earning Per Share Berpengaruh Terhadap Return Saham. E-Jurnal Manajemen, 9(3), 1069-1088.

Amalya, N. T. (2018). Pengaruh return on asset, return on equity, net profit margin dan debt to equity ratio terhadap harga saham. Jurnal SEKURITAS (Saham, Ekonomi, Keuangan Dan Investasi), 1(3).

Azhari, D. F., Rahayu, S. M., \& Zahroh, Z. A. (2016). Pengaruh ROE, DER, TATO, dan PER terhadap Harga saham Perusahaan Properti dan Real Estate yang Go Publik di Bursa Efek Indonesia. Jurnal Administrasi Bisnis, 32(2), 1-5.

Bacidore, J. M., Boquist, J. A., Milbourn, T. T., \& Thakor, A. V. (1997). The search for the best financial performance measure. Financial Analysts Journal, 53(3), 11-20.

Badruzaman, J. (2017). Pengaruh earning per share terhadap harga saham. Jurnal Akuntansi, 12(1), $101-110$.

Barauskaite, G., \& Streimikiene, D. (2021). Corporate social responsibility and financial performance of companies: The puzzle of concepts, definitions and assessment methods. Corporate Social Responsibility and Environmental Management, 28(1), 278-287.

Cochran, P. L., \& Wood, R. A. (1984). Corporate Social Responsibility and Financial Performance. Academy of Management Journal, 27(1), 42-56. https://doi.org/10.5465/255956

Dewi, S. P., \& Hidayat, R. (2019). Pengaruh Net Profit Margin dan Return on Assets terhadap Harga saham pada Perusahaan Otomotif yang terdaftar di Bursa Efek Indonesia. Jurnal Ilman: Jurnal Ilmu Manajemen, 1(1).

Dini, A. W., \& Indarti, I. (2012). Pengaruh Net Profit Margin (NPM), Return On Assets (ROA) Dan Return On Equity (ROE) Terhadap Harga saham Yang Terdaftar Dalam Indeks Emiten LQ45 Tahun 2008-2010. Jurnal Kajian Akuntansi Dan Bisnis, 1(1), 102654.

Egam, G. E. Y., Ilat, V., \& Pangerapan, S. (2017). Pengaruh Return on Asset (ROA), Return on Equity (ROE), Net Profit Margin (NPM), dan Earning Per Share (EPS) terhadap Harga saham Perusahaan yang Tergabung dalam Indeks LQ45 di Bursa Efek Indonesia Periode Tahun 2013-2015. Jurnal EMBA: Jurnal Riset Ekonomi, Manajemen, Bisnis Dan Akuntansi, 5(1).

Firdaus, I., \& Kasmir, A. N. (2021). PENGARUH PRICE EARNING (PER), EARNING PER SHARE (EPS), DEBT TO EQUITY RATIO (DER) TERHADAP HARGA SAHAM. Jurnal Manajemen Dan Bisnis, 1(1), 40-57.

Hadianto, B. (2008). Pengaruh Earnings Per Share (EPS) dan Price Earnings Ratio (PER) Terhadap Harga saham Sektor Perdagangan Besar dan Ritel Pada Periode 2000-2005 di Bursa Efek Indonesia. Jurnal Akuntansi, 7(2), 159-169.

Husaini, A. (2012). Pengaruh Variabel Return On Assets, Return On Equity, Net Profit Margin dan earning Per Share Terhadap Harga saham Perusahaan. Profit: Jurnal Administrasi Bisnis, 6(1).

Hutami, R. P. (2012). Pengaruh Dividend Per Share, Return On Equity Dan Net Profit Margin Terhadap Harga saham Perusahaaan Industri Manufaktur Yang Tercatat Di Bursa Efek Indonesia Periode 2006-2010. Nominal: Barometer Riset Akuntansi Dan Manajemen, 1(2), 104-123.

Munira, M., Merawati, E. E., \& Astuti, S. B. (2018). Pengaruh ROE dan DER Terhadap Harga saham Perusahaan Kertas di Bursa Efek Indonesia. JABE (Journal of Applied Business and Economic), 4(3), 191-205.

Pratama, C. A., Azizah, D. F., \& Nurlaily, F. (2019). Pengaruh Return On Equity (ROE), Earning Per Share (EPS), Current Ratio (CR) Dan Debt To Equity Ratio (DER) Terhadap Harga saham (Studi pada Perusahaan Jakarta Islamic Index yang Terdaftar di Bursa Efek Indonesia Tahun 2014-2017). Jurnal Administrasi Bisnis, 66(1), 10-17.

Ramzan, M., Amin, M., \& Abbas, M. (2021). How does corporate social responsibility affect financial performance, financial stability, and financial inclusion in the banking sector? Evidence from Pakistan. Research in International Business and Finance, 55, 101314.

Rinati, I. (2012). Pengaruh Net Profit Margin (NPM), Return On Assets (ROA) dan Return On Equity (ROE) terhadap harga saham pada perusahaan yang tercantum dalam indeks LQ45.

Safitri, A. L. (2013). Pengaruh Earning Per Share, Price Earning Ratio, Return On Asset, Debt To Equity Ratio dan Market Value Added terhadap Harga saham dalam kelompok Jakarta Islamic 
Index tahun 2008-2011. Universitas Negeri Semarang.

Sakai, K., \& Dillak, V. J. (2021). Pengaruh Return on Equity (ROE), Debt to Equity Ratio (DER), Earning Per Share (EPS) terhadap Harga saham. EProceedings of Management, 7(3).

Samsul, M. (2006). Pasar modal dan manajemen portofolio (S. Yati \& S. Saat (eds.)). Erlangga.

Santy, V. A. D., \& Triyonowati, T. (2017). Pengaruh ROA, ROE, dan EPS terhadap Harga saham PT. Garuda Indonesia Tbk. Jurnal Ilmu Dan Riset Manajemen (JIRM), 6(9).

Susilawati, E. (2014). Pengaruh Rasio Likuiditas, Rasio Solvabilitas, dan Rasio Profitabilitas Terhadap Earning Per Share (Study Kasus Pada Perusahaan Manufaktur yang terdaftar di Bursa Efek Indonesia Periode 2008-2011). Jurnal Akuntansi, 2(1), 88-97.

Valintino, R., \& Sularto, L. (2013). Pengaruh Return On Asset (ROA), Current Ratio (CR), Return On Equity (ROE), Debt To Equity Ratio (DER), dan Earning Per Share (EPS) Terhadap Harga saham Perusahaan Manufaktur Sektor Industri Barang Konsumsi di BEI. Prosiding PESAT, 5.

Watung, R. W., \& Ilat, V. (2016). Pengaruh Return On Asset (Roa), Net Profit Margin (Npm), Dan Earning Per Share (Eps) Terhadap Harga saham Pada Perusahaan Perbankan Di Bursa Efek Indonesia Periode 2011-2015. Jurnal EMBA: Jurnal Riset Ekonomi, Manajemen, Bisnis Dan Akuntansi, 4(2).

Yuliani, Y., \& Supriadi, Y. (2014). Pengaruh Earning Per Share Dan Dividend Per Share Terhadap Harga saham Perusahaan Yang Go Public. Jurnal Ilmiah Manajemen Kesatuan, 2(2), 111-118.

Zutter, C. J., \& Gitman, L. J. (2015). Principles of Managerial Finance (D. Battista (ed.); 14th ed.). Pearson Education Limited.

*Email korespondensi:

nafisdwikartiko@gmail.com 